\title{
(ㄷ)
}

Research Paper

EPRA International Journal of Economic and Business Review-Peer Reviewed Journal

Volume - 9, Issue - 9, September 2021 | e-ISSN: 2347 - 9671| p- ISSN: 2349 - 0187

SJIF Impact Factor (2021): 8.302 || ISI Value: 1.433 || Journal DOI URL: https://doi.org/10.36713/epra2012

\section{AN ECONOMIC ANAYSIS OF GULBARGA ELECTRICITY SUPPLY COMPANY (GESCOM) IN KARNATAKA}

\author{
Dr. Geeta. R. Nandur
}

\begin{abstract}
DOI No: 10.36713/epra8525

Article DOI URL: $\underline{\text { https://doi.org/10.36713/epra8525 }}$

Electricity is a key infrastructural input in the modern economy which increasingly aids in achieving a higher standard of living and rapid economic growth. Its inadequacy or, absence paralyses the functioning of all sectors and leads to economic losses. There is close association between electricity consumption and economic growth. The present study attempts to make the economic analysis of Gulbarga Electricity Supply Company (GESCOM). The study is based on primary data. The data were collected from selected talukas, villages and the sample domestic consumers' in the study area. Total 350 domestic consumers' were selected randomly by adopting a multi stage stratified random sampling for each village. The data analysed with the help of suitable statistical techniques like simple percentage, average, ratio etc. The study finds considerable awareness among the consumers and has they understand the importance of electricity and created the sense of proud about its functioning. The empirical results, further reveal that the practical problems of power cut in the regions.

KEYWORDS: Electricity, Domestic Consumers, Billing, Complaint and GESCOM.
\end{abstract}

\section{INTRODUCTION}

Electricity is a key infrastructural input in the modern economy which increasingly aids in achieving a higher standard of living and rapid economic growth. Its inadequacy or, absence paralyses the functioning of all sectors and leads to economic losses. There is close association between electricity consumption and economic growth. Nevertheless, despite its considerable importance, electricity industry in India has been facing many challenges in various aspects, such as lack of basic access to electricity, energy and peak deficits, capacity utilization, quality supply, and financial condition of the power utilities. To address the problems, widespread reforms were undertaken in Indian power sector since the 1990s. Beginning mainly from the allowance of private sector participation in generation in 1991, the State Electricity Boards (SEBs) were restructured, regulatory commissions were established and finally, all the power sector legislations were subsumed under the Electricity Act, 2003, which aimed to increase competition and efficiency in the sector. Providing electricity to all by 2012 and elimination of energy and peak shortages were targeted in the National Electricity Policy 2005 by the central government. Due to persisting deficit and inadequate access, Government of India launched the "24*7 Power for All Initiativell in 2014, in collaboration with the state governments to provide $24 * 7$ power access to all by 2019 (Ministry of Power, 2014). In addition, numerous policies and schemes were launched at central and state level to address many technical and financial bottlenecks in the sector. 


\section{OBJECTIVES OF THE STUDY}

1) To make economic analysis of Gulbarga Electricity Supply company (GESCOM).

2) To suggest suitable policy measures to improve the economic efficiency of GESCOM.

\section{METHODOLOGY}

Data Collection: The study is based on primary data. The primary data is collected through specially designed interview schedules.

Sampling Design:-Primary data was collected by using multi stage stratified sampling technique .In the first stage 7 talukas of Gulbarga district, viz; Afzalpur, Aland, Chincholi, Chittapur, Gulbarga, Jewargi, and
Sedam are selected. In the second stage 7 villages from the above talukas viz,Chowdapur (Afzalpur), MadanHipparga (Aland), Aloor (Chittapur) , Nandikoor (Gulbarga),Nelogi (Jewargi), Sulepet (Chincholi) and Bannur (Sedam). A multi stage stratified random sampling techniques were randomly adopted to selected. In the third stage sample of 350 respondents were randomly selected. This sample includes only domestic consumers'. This accounts for $5 \%$ of total households of seven talukas.

Data Analysis:-The data analysed with the help of suitable statistical techniques like simple percentage, average, ratio etc.

\section{RESULTS AND DISCUSSION}

Table -1

Distribution of Respondents by Sex

\begin{tabular}{|c|c|c|c|c|}
\hline Sl.No. & Gender & Rural & Urban & Total \\
\hline 1. & Male & $\begin{array}{c}127 \\
(72.57)\end{array}$ & $\begin{array}{c}118 \\
(67.42)\end{array}$ & $\begin{array}{c}245 \\
(70.00)\end{array}$ \\
\hline 2. & Female & $\begin{array}{c}48 \\
(27.42)\end{array}$ & $\begin{array}{c}57 \\
(32.57)\end{array}$ & $\begin{array}{c}105 \\
(30.00)\end{array}$ \\
\hline & Total & $\begin{array}{c}\mathbf{1 7 5} \\
\mathbf{( 1 0 0 . 0 0})\end{array}$ & $\begin{array}{c}\mathbf{1 7 5} \\
\mathbf{( 1 0 0 . 0 0 )}\end{array}$ & $\begin{array}{c}\mathbf{3 5 0} \\
(\mathbf{1 0 0 . 0 0})\end{array}$ \\
\hline
\end{tabular}

Source: Field Survey.

The data presented in the table 1 indicate that majority of the respondents are males, representing about $127(72.57 \%)$ in rural and in urban $118(67.42 \%)$, whereas $48(27.42 \%)$ in rural females and $57(32.57 \%)$ in urban. Among the respondents most of them were

from rural who said that the facilities given by the GESCOM are satisfactory and most of the respondents from urban said that the facilities given by the GESCOM are not satisfactory.

Table - 2

Domestic Lighting Arrangement

\begin{tabular}{|c|l|c|c|c|}
\hline Sl. No. & \multicolumn{1}{|c|}{ Domestic Lighting } & Rural & Urban & Total \\
\hline 1 & No electricity & 5 & 00 & 5 \\
& & $(02.90)$ & $(0.00)$ & $(01.42)$ \\
\hline 2 & Bhagya Jyothi & 63 & 66 & 129 \\
& & $(36.00)$ & $(37.71)$ & $(36.85)$ \\
\hline 3 & Electricity with meter & 99 & 109 & 208 \\
& & $(56.60)$ & $(62.30)$ & $(59.42)$ \\
\hline 4 & Any other & 8 & 00 & 08 \\
& & $(04.60)$ & $(0.00)$ & $(02.28)$ \\
\hline & Total & $\mathbf{1 7 5}$ & $\mathbf{1 7 5}$ & $\mathbf{3 5 0}$ \\
& & $(\mathbf{1 0 0})$ & $(\mathbf{1 0 0})$ & $(\mathbf{1 0 0})$ \\
\hline
\end{tabular}

Source: Field Survey.

Table 2 explains about the lighting arrangement in their houses. The analysis of the data shows that, about $208(59.42 \%)$ of the total said that Electricity with meter showed good responses i.e., in rural $99(56.60 \%)$ and in urban $109(62.30 \%)$, followed by Bhagya Jyothi about 129 (36.85\%) i.e., from rural $63(36.00 \%)$ and from urban $66(37.71 \%)$ said that it is more essential to urban poor and very few respondents said that there is no electricity in their houses, about 5 $(1.42 \%)$ i.e., rural $5(2.90 \%)$ and from urban. 
Table $-\mathbf{3}$

Electrical Household Appliance Using By Respondents

\begin{tabular}{|c|c|c|l|l|}
\hline Appliances & Rural & Urban & Total & \multicolumn{1}{c|}{$\%$} \\
\hline Lights & 175 & 175 & 350 & 100.00 \\
\hline Fans & 175 & 175 & 350 & 100.00 \\
\hline Iron Box & 120 & 175 & 295 & 84.29 \\
\hline Refrigerator & 30 & 78 & 108 & 30.86 \\
\hline Television & 175 & 175 & 350 & 100.00 \\
\hline Radio & 35 & 58 & 93 & 26.57 \\
\hline Mixer & 88 & 170 & 258 & 73.71 \\
\hline Washing machine & 02 & 22 & 24 & 6.86 \\
\hline Computer & 03 & 38 & 41 & 11.71 \\
\hline Water heater & 76 & 120 & 196 & 56.00 \\
\hline Electric stove & 08 & 33 & 41 & 11.71 \\
\hline VCD player & 02 & 40 & 42 & 12.00 \\
\hline
\end{tabular}

Source: Field Survey.

Table 3 indicates the electrical appliances using by the respondents in their houses in the study area. In both areas 100 per cent of the respondents are using the lights, fans and television in their houses, 84.29 per cent of the respondents have been using iron box, 73.71 per cent of the respondents are using mixer, 56 per cent of the respondents have been using water heater and lower per cent of the respondents are using refrigerator, radio, washing machine, computer, electric stove and VCD player.

Table -4

Prior Information of Power Cuts

\begin{tabular}{|c|l|c|c|c|}
\hline Sl. No. & \multicolumn{1}{|c|}{ Prior Information } & Rural & Urban & Total \\
\hline 1 & Informed & 21 & 36 & 57 \\
& & $(12.00)$ & $(20.57)$ & $(16.28)$ \\
\hline 2 & Not informed & 93 & 97 & 190 \\
& & $(53.15)$ & $(55.43)$ & $(54.28)$ \\
\hline 3 & Sometime information & 39 & 27 & 66 \\
& & $(22.28)$ & $(15.43)$ & $(18.86)$ \\
\hline 4 & Not Answer & 22 & 15 & 37 \\
& & $(12.57)$ & $(08.57)$ & $(10.58)$ \\
\hline & Total & $\mathbf{1 7 5}$ & $\mathbf{1 7 5}$ & $\mathbf{3 5 0}$ \\
& & $\mathbf{( 1 0 0 )}$ & $\mathbf{( 1 0 0 )}$ & $\mathbf{( 1 0 0 )}$ \\
\hline
\end{tabular}

Source: Field Survey.

Power cut is the major problem in this region. The government officials are unable to inform to the consumers priority about the power cut. This is a major issue, the consumers are facing today. From the above table 4, it clear that about 190 (54.28\%) i.e., from rural $(53.15 \%)$ and from urban $97(55.43 \%)$ said that they are not informed about the power cuts. About 66 $(18.86 \%)$ i.e., from rural $39(22.28 \%)$ and from urban $27(15.43 \%)$ said that sometimes information is given to consumers about the power cut. And the rest of the respondents said that they are informed about the power cut in their regions about $190(54.28 \%)$ i.e., from rural $21(12.00 \%)$ and from urban $36(20.57 \%)$ showed good results about the information they have got from the government officials, and the rest of the respondents had not answered about 37 (10.58\%), i.e., from rural $22(12.57 \%)$ and from urban $15(8.57 \%)$ complained about the facilities by the government. 
Table -5

Alternatives Used During Power Cuts

\begin{tabular}{|c|l|c|c|c|}
\hline Sl. No. & \multicolumn{1}{|c|}{ Alternative Uses } & Rural & Urban & Total \\
\hline 1 & Did nothing & 92 & 24 & 116 \\
& & $(52.58)$ & $(13.72)$ & $(33.14)$ \\
\hline 2 & Kerosene lamp & 34 & 20 & 54 \\
& & $(19.43)$ & $(11.43)$ & $(15.43)$ \\
\hline 3 & Candles & $(16.57)$ & $(14.85)$ & 55 \\
& & 3 & 23 & 26 \\
& & $(01.72)$ & $(13.15)$ & $(07.43)$ \\
\hline 4 & Used an emergency lamp & 7 & 57 & 64 \\
& & $(4.0)$ & $(32.57)$ & $(18.28)$ \\
\hline 5 & Used an inverter & 5 & 25 & 30 \\
& & $(02.86)$ & $(14.28)$ & $(08.57)$ \\
\hline 6 & Used a generator & 5 & 0 & 5 \\
& & $(02.85)$ & $(0.0)$ & $(01.43)$ \\
\hline 7 & any other & $\mathbf{1 7 5}$ & $\mathbf{1 7 5}$ & $\mathbf{3 5 0}$ \\
& & $\mathbf{( 1 0 0 . 0 0 )}$ & $(\mathbf{1 0 0 . 0 0})$ & $(\mathbf{1 0 0 . 0 0})$ \\
\hline & & & & \\
& & & & \\
& & & &
\end{tabular}

Source: Field Survey.

The above table 5 revealed alternatives used during the power cuts. Among all the respondents 116 $(33.14 \%)$ respondents felt that they are unable to do anything during the power cuts i.e., from rural 92 $(52.58 \%)$ and from urban $24(13.72 \%)$ showed poor performance during the power cuts. Whereas 64 (18.28\%) i.e., from rural $7(4.0 \%)$ and from urban 57 $(32.57 \%)$ said that they use inverter in their houses during the power cuts. About 54 (15.43\%) i.e., from rural $34(19.43 \%)$ and from urban $20(11.43 \%)$ said they use kerosene lamp in their houses during the power cuts, and $55(15.72 \%)$ i.e., from rural 29 $(16.57 \%)$ and from urban $26(14.85 \%)$ said they use candles. Rest of the respondents said they use generator about $30(8.57 \%)$ i.e., from rural $5(2.86 \%)$ and from urban $25(14.28 \%)$ and a very few respondents did not respond much about the power cut in their houses.

Table -6

Response by the Staff against Complaints Regarding Line Fault

\begin{tabular}{|c|l|c|c|c|}
\hline Sl. No. & Response by staff & Rural & Urban & Total \\
\hline 1 & Same day & $\begin{array}{c}78 \\
(44.57)\end{array}$ & $\begin{array}{c}97 \\
(55.43)\end{array}$ & $\begin{array}{c}175 \\
(50.00)\end{array}$ \\
\hline 2 & Within2 days & $\begin{array}{c}42 \\
(24.00)\end{array}$ & $\begin{array}{c}51 \\
(29.15)\end{array}$ & $\begin{array}{c}93 \\
(26.57)\end{array}$ \\
\hline 3 & 7 to 15 days & 21 & 15 & 36 \\
& & $(12.00)$ & $(08.57)$ & $(10.28)$ \\
\hline 4 & 1 month & 12 & 12 & 24 \\
& & 9 & 0 & $(06.85)$ \\
\hline 5 & After one month & $(05.15)$ & $(00.00)$ & $\begin{array}{c}9 \\
(02.57)\end{array}$ \\
\hline 6 & Don't know & $\begin{array}{c}13 \\
(07.43)\end{array}$ & $\begin{array}{c}0 \\
(00.00)\end{array}$ & $\begin{array}{c}13 \\
(03.72)\end{array}$ \\
\hline & & $\mathbf{1 7 5}$ & $\mathbf{1 7 5}$ & $\mathbf{3 5 0}$ \\
& & $(\mathbf{1 0 0 . 0 0})$ & $(\mathbf{1 0 0 . 0 0})$ & $\mathbf{( 1 0 0 )}$ \\
\hline
\end{tabular}

Source: Field Survey.

The major problem is power cut and some inconvenience faced by the consumers for which they had to complain to the office staff and consumer shows this response of in the table 6 , It reveals that about 175
(50.00\%) i.e., from rural $78(44.57 \%)$ and $97(55.43 \%)$ of the consumers are facing major problems daily in rural and urban places due to power cut. Whereas, about $93(26.57 \%)$ i.e., from rural $42(24.00 \%)$ and 
from urban $51(29.15 \%)$ are facing problems for the last 2 days, and $36(10.28 \%)$ i.e., from rural 21 $(12.00 \%)$ and from urban $15(8.57 \%)$ are facing the problems from the last 7 to 15 days especially in urban areas. But most of the respondents are facing problems from 1 month the total $24(6.86 \%)$ i.e., from rural 12 $(6.85 \%)$ and from urban $12(6.85 \%)$ and there is no response from the officials, the most of the respondents are facing problems in urban areas and even after a month, the problem has not been solved due to their negligence towards the consumers the responses were $9(2.57 \%)$ i.e., from rural $9(5.15 \%)$ and no responses from urban, and some respondents didn't want to know why the problem is created about was 13 of them (3.72\%) i.e., from rural $13(7.43 \%)$ and from urban no responses was given because of lack of awareness.

Table -7

Period of Billing

\begin{tabular}{|c|l|c|c|c|}
\hline Sl. No. & Period & Rural & Urban & Total \\
\hline 1 & Monthly & $\begin{array}{c}21 \\
(12)\end{array}$ & $\begin{array}{c}30 \\
(17.15)\end{array}$ & $\begin{array}{c}51 \\
(14.57)\end{array}$ \\
\hline 2 & Once in two month & $\begin{array}{c}79 \\
(45.15)\end{array}$ & $\begin{array}{c}75 \\
(42.85)\end{array}$ & $\begin{array}{c}154 \\
(44)\end{array}$ \\
\hline 3 & Once in three month & $\begin{array}{c}39 \\
(22.28)\end{array}$ & $\begin{array}{c}36 \\
(20.57)\end{array}$ & $\begin{array}{c}75 \\
(21.43)\end{array}$ \\
\hline 4 & Any other & 36 & 34 & 70 \\
& & $(20.57)$ & $(19.43)$ & $(20.00)$ \\
\hline & Total & 175 & 175 & 350 \\
& & $(100)$ & $(100)$ & $(100)$ \\
\hline
\end{tabular}

Source: Field Survey.

Majority of the respondents belonging to rural areas are unable to afford to pay the bill on time because of the lack of facilities from the government. From the above table 7, it is clear that about $154(44.00 \%)$ i.e., from rural $79(45.15 \%)$ and from urban $75(42.85 \%)$ had agreed to pay the bill once in two months, whereas about 75 (21.43\%) i.e., from rural 39 (22.28\%) and from urban 34
(19.43\%) had agreed to pay the bill once in three months and some of the respondents who had agreed to pay the bill monthly about $51(14.57 \%)$ i.e., from rural 21 $(12.00 \%)$ and among the urban $30(17.15 \%)$. Some of the respondents said that they pay the bill any time about 70 $(20.00 \%)$ i.e., from rural $36(20.57 \%)$ and from urban 34 $(19.43 \%)$.

\section{Table -8}

Average Bill per Month

\begin{tabular}{|c|l|c|c|c|}
\hline Sl.No. & \multicolumn{1}{|c|}{ Bill Per Month } & Rural & Urban & Total \\
\hline 1 & $<100$ & $\begin{array}{c}93 \\
(53.15)\end{array}$ & $\begin{array}{c}51 \\
(29.14)\end{array}$ & $\begin{array}{c}164 \\
(46.86)\end{array}$ \\
\hline 2 & 101 to 200 & $\begin{array}{c}51 \\
(29.15)\end{array}$ & $\begin{array}{c}58 \\
(33.14)\end{array}$ & $\begin{array}{c}120 \\
(34.28)\end{array}$ \\
\hline 3 & 201 to 500 & $\begin{array}{c}19 \\
(10.85)\end{array}$ & $\begin{array}{c}42 \\
(24)\end{array}$ & $\begin{array}{c}42 \\
(12.00)\end{array}$ \\
\hline 4 & 501 and above & 12 & 24 & 24 \\
& & $(06.85)$ & $(13.72)$ & $(06.86)$ \\
\hline & Total & $\mathbf{1 7 5}$ & $\mathbf{1 7 5}$ & $\mathbf{3 5 0}$ \\
& & $\mathbf{( 1 0 0 )}$ & $\mathbf{( 1 0 0 )}$ & $\mathbf{( 1 0 0 )}$ \\
\hline
\end{tabular}

Source: Field Survey.

The present study explores the payment of bill per month in the sample area. The data is reported in table 8 . The payment of bill per month in total sample is, $164(46.86 \%)$ i.e., from rural $93(53.15 \%)$ and from urban $51(29.14 \%)$ who have less than 100 per month, while $120(34.28 \%)$ i.e., from rural 51 (29.15\%) and from urban $58(33.14 \%)$ have 101 to 200 per month, whereas from 201 to 500 the respondents have the total of $42(12.00 \%)$ i.e., from rural $19(10.85 \%)$ and from urban $42(24.00 \%)$ and very few of the respondents have $24(6.86 \%)$ i.e., from rural $12(6.85 \%)$ and from urban $24(13.72 \%)$ are from 501 and above. 
Table -9

Regularity in Payment

\begin{tabular}{|c|l|c|c|c|}
\hline Sl.No. & Payment of bill & Rural & Urban & Total \\
\hline 1 & Regular & 161 & 133 & 294 \\
& & $(92)$ & $(76)$ & $(84.00)$ \\
\hline 2 & Not regular & 14 & 42 & 56 \\
& & $(8)$ & $(24)$ & $(16.00)$ \\
\hline & Total & $\mathbf{1 7 5}$ & $\mathbf{1 7 5}$ & $\mathbf{3 5 0}$ \\
& & $\mathbf{( 1 0 0 )}$ & $\mathbf{( 1 0 0 )}$ & $\mathbf{( 1 0 0 )}$ \\
\hline
\end{tabular}

Source: Field Survey.

Table 9 shows the regularity in payment of electricity bill. Most of the respondents are regular in paying the electricity bill, who are about 294 (84.00\%) i.e., from rural $161(92.00 \%)$ and from urban 133

Table -10

Payment of Bill

\begin{tabular}{|c|c|c|c|c|}
\hline Sl.No. & Payment of Bill & Rural & Urban & Total \\
\hline 1 & Cash & $\begin{array}{c}175 \\
(100)\end{array}$ & $\begin{array}{c}101 \\
(57.72)\end{array}$ & $\begin{array}{c}276 \\
(78.85)\end{array}$ \\
\hline 2 & Cheque & 0 & 74 & 74 \\
& & $(0.00)$ & $(42.28)$ & $(21.15)$ \\
\hline 3 & Online & 0 & 0 & 0 \\
& & $(0.00)$ & $(0.00)$ & $(0.00)$ \\
\hline & Total & $\mathbf{1 7 5}$ & $\mathbf{1 7 5}$ & $\mathbf{3 5 0}$ \\
& & $(\mathbf{1 0 0 . 0 0})$ & $\mathbf{( 1 0 0 . 0 0 )}$ & $\mathbf{( 1 0 0 . 0 0 )}$ \\
\hline
\end{tabular}

Source: Field Survey.

The above table 10 explains about payment of bills is $275(78.85 \%)$ respondents were satisfied by paying the bill in cash mode i.e., from rural 175 (100\%) and from urban $101(57.72 \%)$, whereas some respondents said that they pay the bill in cheque about

Table -11

Metering of Bhagya Jyothi

\begin{tabular}{|c|l|c|c|c|}
\hline Sl.No. & \multicolumn{1}{|c|}{ Bhagya Jyothi } & Rural & Urban & Total \\
\hline 1 & Metering & $\begin{array}{c}107 \\
(61.15)\end{array}$ & $\begin{array}{c}97 \\
(55.43)\end{array}$ & $\begin{array}{c}204 \\
(58.28)\end{array}$ \\
\hline 2 & Not metering & $\begin{array}{c}68 \\
(38.85)\end{array}$ & $\begin{array}{c}78 \\
(44.57)\end{array}$ & $\begin{array}{c}146 \\
(41.72)\end{array}$ \\
\hline & & $\mathbf{1 7 5}$ & $\mathbf{1 7 5}$ & $\mathbf{3 5 0}$ \\
& Total & $(\mathbf{1 0 0 . 0 0 )}$ & $(\mathbf{1 0 0 . 0 0})$ & $(\mathbf{1 0 0 . 0 0 )}$ \\
\hline
\end{tabular}

Source: Field Survey.
Government has made better arrangements for those people who belonged to minority level under the scheme Bhagya Jyothi in rural and urban areas. Table 11 shows the metering of Bhaygya Jyothi. Most of the respondents were under the scheme of Bhagya Jyothi with meter about $204(58.28 \%)$ of them i.e., from rural $107(61.15 \%)$ and from urban $97(55.43 \%)$ most of the
$(76.00 \%)$, whereas some of the respondents are not regular in paying electricity bill about $56(16.00 \%)$ i.e., from rural $14(8.00 \%)$ and from urban $42(24.00 \%)$.
$74(21.15 \%)$ of them i.e., from rural no respondents were available but from urban $74(42.28 \%)$ pay bill in Cheque, but there was no response from respondents to pay the bill online.
100.00

people from rural areas are happy under the Bhagya Jyothi scheme, whereas, those respondents who are not having meter about 146 (41.72\%) of them i.e., from rural $68(38.85 \%)$ and from urban $78(44.57 \%)$ were getting the benefits of this scheme. 
Table -12

Opinion about Complaints Attended

\begin{tabular}{|c|c|c|c|c|}
\hline Sl.No. & Complaints attended & Rural & Urban & Total \\
\hline 1 & Yes & $\begin{array}{c}128 \\
(73.15)\end{array}$ & $\begin{array}{c}143 \\
(81.72)\end{array}$ & $\begin{array}{c}271 \\
(77.43)\end{array}$ \\
\hline 2 & No & 22 & 7 & 29 \\
$(12.57)$ & $(4)$ & $(08.29)$ \\
\hline 3 & Don't Know & 25 & 25 & 50 \\
& & $(14.28)$ & $(14.28)$ & $(14.28)$ \\
\hline & Total & $\begin{array}{c}\mathbf{1 7 5} \\
(\mathbf{1 0 0 . 0 0})\end{array}$ & $\begin{array}{c}\mathbf{1 7 5} \\
(\mathbf{1 0 0 . 0 0})\end{array}$ & $\begin{array}{c}\mathbf{3 5 0} \\
(\mathbf{1 0 0 . 0 0})\end{array}$ \\
\hline
\end{tabular}

Source: Field Survey.

The satisfaction of consumers towards the complaints attended is explained in the above table 12 . The data demonstrated in the above table explains that an overwhelming majority of the respondents i.e., 271 (77.43\%) strongly opined that they are satisfied with their complaints given immediately i.e., from rural 128
$(73.15 \%)$ and from urban $143(81.72 \%)$, whereas rest of the respondents said not satisfied towards the complaints about $29(8.29 \%)$ i.e., from rural 22 $(12.57 \%)$ and $7(4.0 \%)$ and some of them said that they don't know about $50(14.28 \%)$ i.e., from rural 25 $(14.28 \%)$ and from urban $25(14.28 \%)$.

Table -13

Opinion about Helpline Number

\begin{tabular}{|c|l|c|c|c|}
\hline Sl.No. & \multicolumn{1}{|c|}{ Helpline Number } & Rural & Urban & Total \\
\hline 1. & Satisfied & $\begin{array}{c}84 \\
(48.00)\end{array}$ & $\begin{array}{c}70 \\
(40.00)\end{array}$ & $\begin{array}{c}154 \\
(44.00)\end{array}$ \\
\hline 2. & Not Satisfied & 91 & 105 & 196 \\
& & $(52.00)$ & $(60.00)$ & $(56.00)$ \\
\hline & Total & $\mathbf{1 7 5}$ & $\mathbf{1 7 5}$ & $\mathbf{3 5 0}$ \\
& & $\mathbf{( 1 0 0 )}$ & $\mathbf{( 1 0 0 )}$ & $\mathbf{( 1 0 0 )}$ \\
\hline
\end{tabular}

Source: Field Survey.

The above table 13 shows the opinion about helpline number. In the opinion of majority of the respondents about $154(44.0 \%)$ felt that they are satisfied with the helpline number i.e., from rural 84

$(48.00 \%)$ and from urban $70(40.00 \%)$ and rest of them said not satisfied about $196(56.00 \%)$ i.e., from rural 91 $(52.00 \%)$ and $105(60.00 \%)$ showed no interest in helpline number.

Table -14

About GESCOM

\begin{tabular}{|c|c|c|c|c|}
\hline Sl.No. & GESCOM & Rural & Urban & Total \\
\hline 1 & Yes & $\begin{array}{c}155 \\
(88.57)\end{array}$ & $\begin{array}{c}171 \\
(97.72)\end{array}$ & $\begin{array}{c}326 \\
(93.15)\end{array}$ \\
\hline 2 & No & $\begin{array}{c}20 \\
(11.43)\end{array}$ & $\begin{array}{c}4 \\
(02.28)\end{array}$ & $\begin{array}{c}24 \\
(06.85)\end{array}$ \\
\hline & & $\mathbf{1 7 5}$ & $\mathbf{1 7 5}$ & $\mathbf{3 5 0}$ \\
& Total & $\mathbf{( 1 0 0 )}$ & $\mathbf{( 1 0 0 )}$ & $\mathbf{( 1 0 0 )}$ \\
\hline
\end{tabular}

Source: Field Survey.

The table 14 shows the responses about GESCOM. Most of the respondents are satisfied about $326(93.15 \%)$ of them i.e., from rural $155(88.57 \%)$ and from urban $171(97.72 \%)$ have given good response about GESCOM, whereas, the rest of the respondents are not satisfied about GESCOM facilities provided to them about $24(6.85 \%)$ i.e., from rural 20 (11.43\%) and from urban $4(2.28 \%)$.

\section{SUGGESTIONS FOR THE STUDY}

1. The GESCOM units must be setup in every village to address the customer's complaints immediately.

2. Innovative methods and policies must be framed for the effective functioning of GESCOM.

3. The Wastage and misuse of power must be urgently prevented as it is believed that energy production itself is energy saving. 
4. Public awareness about the importance of role must be highlighted both in rural and urban areas of the state.

5. An alternative energy sources such as wind energy, solar energy, and ocean energy etc are generated and used extensively.

\section{CONCLUSION}

The empirical results based on analysis of the data collected from the study area, i.e., shows that there is a sizable increase in the number of units of GESCOM in both rural and urban areas. This study finds considerable awareness among the consumers and has they understand the importance of electricity and created the sense of proud about its functioning. The empirical results, further reveal that the practical problems of power cut in the regions. This study also finds that there is an increase in the rate of complaints regarding shortage of services .The study also points out that the number of consumer complaints are about customer service helpline, and also about the supply of electricity etc for which the rural respondents demand an immediate action for the supply of power for their lands.

\section{REFERENCES}

1. Banerjee, Nimala (1979). Demand for Electricity, Centre for studies in social science, Calcutta, K.P. Bagchi and Co., Calcutta.

2. Degaonkar, C.K (2001) "A development plan for Hyderabad Karnataka Region”, Department of Economics, Gulbarga University, Gulbarga.

3. Government of Karnataka (1987).A Report on Long Range plan for Power Project in Karnataka 1987-2000.

4. Geeta. Ramu. Nandur (2016) "Economic Analysis of Power Distribution Companies in Karnataka: A Case Study of Gulbarga Electricity Supply Company (GESCOM)", Ph.D Thesis, Gulbarga University, Gulbarga. 